\title{
NUTRITIONAL EVALUATION OF QUINOA (CHENOPODIUM QUINOA WILLD) CROP AS UNCONVENTIONAL FORAGE RESOURCE IN FEEDING RUMINANTS
}

\author{
R. Salama ${ }^{1}$; M. H. Yacout ${ }^{2}$; M. I. T. Elgzar ${ }^{2}$ and A. A. Awad ${ }^{1}$ \\ ${ }^{1}$ Animal Production Department, Faculty of Agriculure, Al-Azhar University, Cairo, Egypt. \\ ${ }^{2}$ Animal Production Researsh Institute (APRI), Agriculture Reseash Center (ARC), Dokki, Giza, \\ Egypt.
}

(Received 23/2/2021, accepted 23/3/2021)

\section{SUMMARY}

\begin{abstract}
$\mathrm{T}$ Wenty lactating Ossimi ewes were randomly distributed according to weight and their average milk yield into 4 groups, (5 ewes each). One group fed berseem hay (BH) (Triforum alxanderinum); the second group fed, quinoa hay $(\mathrm{QH})$; the third group fed corn silage(CS), while the fourth group was fed quinoa silage (QS). All groups were offered similar amounts of barley grains (500 $\mathrm{g} / \mathrm{h} / \mathrm{d}$ ) as concentrate feed, while hay or silage was offered $a d$ lib. Results showed that silage characteristics of quinoa and corn at opening time were good. Fiber fractions (\%) as NDF, ADF, ADL, hemicellulose and cellulose were higher for quinoa hay followed by quinoa and corn silages, while berseem hay recorded the lowest values. Digestion coefficient of DM, OM, CP and nutritive values (TDN\% and DCP\%) were higher $(\mathrm{P}<0.05)$ for corn silage and berseem hay rations compared with quinoa. Nitrogen intake (NI), retention (NR) and as $(\mathrm{NR})$, percentage of $\mathrm{N}$-intake $(\mathrm{NI})$, was significantly $(\mathrm{P}<0.05)$ different in favor of berseem hay; $4 \%$ fat corrected milk $(\mathrm{FCM})$ and protein yields were higher $(\mathrm{P}<0.05)$ for corn silage and berseem hay rations, followed by quinoa. It was concluded that quinoa can be cultivated during forage scarcity in drought affected regions, as well as in an infertile lands. And from nutritional point of view, quinoa silage or hay are valid substitutions to medium quality roughages in feeding ruminants.
\end{abstract}

Keywords: Ewes, quinoa silage or hay, berseem hay, corn silage, digestibility, nutritive value and milk production.

\section{INTRODUCTION}

Quinoa leaves are widely used as food for humans and livestock (Repo-Carrasco et al., 2003) and constitute an inexpensive source of vitamins and minerals. The correlation between the nutrient content of a leaf and its age (as shown by its position on the plant) is an important factor in favoring leaves for harvesting. Chenopodium quinoa leaves have more protein and minerals than commonly consumed spinach and cabbage, but less than amaranth leaves. Quinoa requires short day lengths and cool temperature for normal growth. This crop is somewhat drought tolerant with a water requirement of 10 to 15 in. per year (precipitation and irrigation combined on sandy-loam or loamy-sand soils). These soils have poor or excessive drainage, low natural fertility, or more acidic ( $\mathrm{pH} 4.8)$ to alkaline (8.5) conditions. Nowadays this crop was grown in (Green Egypt Desert Society), Wady Elnatron city, Behira governrate. Chenopodium quinoa could be a valuable forage crop for dairy farms when used as hay or ensiled, with good yields and high protein content (Darwinkel and Stolen, 1998). Conservation by ensiling process has been widely practiced in Europe for a long time. In Netherlands, (Van Schooten and Pinxterhuis, 2003) found that quinoa seemed promising when it was grown for whole crop silage. (Oscar et al., 1995) in Maxico used quinoa as a forage for ruminants, typically have a high concentration of NDF, (Papastylianou et al. 2014; Ruiz et al., 1995 and Weiss, 1993). The objective of this study was to evaluate nutritive value of quinoa and how it can be introduced as un-conventional forage in Egypt compared to berseem hay or corn silage. 


\section{MATERIALS AND METHODS}

The present study was carried out through the period (2017 - 2018) to justify the effect of quinoa hay $(\mathrm{QH})$ or silage $(\mathrm{QS})$ on the performance of lactating ewes compared with berseem hay $(\mathrm{BH})$ or corn silage (CS). Quinoa was harvested before seed setting (after 90 days), left to be sun dried in orded to make hay, or chopped into $0.5-2.0 \mathrm{~cm}$ pieces to make a whole crop silage (WCS). The silo was kept for three months before quinoa was fed.

\section{Quinoa and corn silage preparation:}

The chopped plants (quinoa or corn) were ensiled on the ground in two horizontal silos with two walls (one for each crop). Molasses was added at 5\% (on DM basis) to the whole quinoa stalks before ensiling to provide fast fermentable carbohydrates. The heaps were ensiled in two horizontal wall silos $(2 \times 3 \times 1.5$ $\mathrm{m}$ each).

In order to ensure good consolidation for each layer after filling, the whole silos were pressed by labor's feet, covered carefully by plastic sheets and pressed hardly by soil and some stone blocks. Silos were opened for feeding after 3 months ensiling period. The two silos were opened from one side only. At the opening time, colour and odour were directly examined and dry matter determination was conducted using drying oven at $105{ }^{\circ} \mathrm{C}$ for 24 hours. Representative samples were taken from corn and quinoa silage heaps to measure $\mathrm{pH}$ (immediately) using digital $\mathrm{pH}$, while other samples were kept frozen, stored at (- 20

${ }^{0} \mathrm{C}$ ) to be used later for chemical analysis. The concentrations of TVFA's were determined according to the method of Warner, (1964). Ammonia- N, lactic acid and individual VFA's were analyzed according to the methods described by Everson et al., (1971). Neutral detergent fiber (NDF), acid detergent fiber (ADF) and acid detergent lignin (ADL) were determined according to Van Soest, (2010). Cellulose and hemicellulose were accordingly predicted.

\section{Quinoa and berseem hay preparation:}

Quinoa stalks were harvested (90 days), spread in rows and layers of range $10-25 \mathrm{~cm}$ height, while berseem ( $3-4^{\text {th }}$ cuts) was cut to $10 \mathrm{~cm}$ in length, far from the land and spread on ground in rows and layers of range $10-25 \mathrm{~cm}$ height. Quinoa and berseem were daily turned, upside down in the morning, after dew disappearance until used in digestibility trials. Samples were taken from each hay for later chemical analysis.

\section{Experimental rations:}

Four experimental rations were prepared and offered to the different respective groups, as follows:

$\mathrm{R} 1$; Berseem hay $(\mathrm{BH})$ and served as a control (C1), R2; quinoa hay (QH), R3; corn silage (CS) as a control (C2) and R4; quinoa silage (QS). Animals were assigned to be fed one of such rations $a d$ lib, in addition to $500 \mathrm{~g}$ barley grains/ animal/ day. Water and veterinary care were available all the day time, and daily feed consumption was recorded.

\section{Digestibility Trial:}

Twelve Rams (60 kg, live body weight) were used in digestibility trials (three rams / treatment). The trial lasted for three weeks as a preliminary period followed by one week as a collection period. The digestibility trial was conducted as described by El-Shazly (1958). Feed, feces and urine analysis were carried out according to the methods of A.O. A. C. (2012).

\section{Lactation Trial:}

Twenty lactating Ossimi ewes were randomly distributed according to their milk yield into four groups ( 5 each) blocked for milk yield. Rations were fed twice a day at 8.00 and 16.00 p.m. Ewes were milked twice daily and milk samples were taken during the last 10 days of each period at 8.00 and 16.00. Actual milk yields were daily recorded and milk samples were taken and kept at $4{ }^{\circ} \mathrm{C}$ for latter analysis. Fat corrected milk (4\%) was calculated using the following equation:

$$
\mathrm{FCM}=0.4 \mathrm{M}+15.0 \mathrm{~F} \text {, where } \mathrm{M}=\text { milk yield }(\mathrm{kg}) \text { and } \mathrm{F}=\text { fat yield }(\mathrm{kg})
$$

Milk fat percentage was determined according to Gerber's method as described by Ling (1963), while total solids in percent (TS), total protein and ash were determined according to the standard methods of AOAC (2012). 


\section{Statistical analysis:}

Data obtained were statistically analyzed as a completely randomized design by analysis of variance (ANOVA) using the statistical package software SAS version 9 (SAS 2002) Comparisons between treatment means were made by $F$-test and the least significant differences (LSD) at level $P=0.05$. Duncan's multiple range test was used to test the significance between means (Duncan, 1955).

One way analysis of variance was adopted using the following equation: $Y_{\mathrm{i} j}=\mu+T_{\mathrm{i}}+R_{j}+E_{\mathrm{i} j}$

Where : $Y_{\mathrm{ij}}=$ The observation of the parameter measured., $\mu=$ Overall means., $\mathrm{T}_{\mathrm{i}}=$ The effect of dietary treatment, $\mathrm{R}_{\mathrm{J}}=$ The effect of replication, and $\mathrm{E}_{\mathrm{ij}}=$ The random error term

\section{RESULTS AND DISCUSSION}

Results illustrated in Table (1) showed silage characteristics of both quinoa and corn at zero and opening time. Values of $\mathrm{pH}$ showed that both silages had optimum $\mathrm{pH}$ values (4.02 and 4.36 for quinoa and corn, respectively). These could be indicated for good quality silage. However, $\mathrm{pH}$ values for quinoa was more than that of corn; this could be related to the lower concentration of quinoa TVFA's than that in corn silage (3.95 vs. $5.22(\mathrm{meq} / \mathrm{g})$.

The reduction in TVFA's values could be attributed to the decrease in lactic and acetic acid production, causing fast drop in $\mathrm{pH}$ value and so inhibited the activity of VFA's producing bacteria. These results are in agreement with the findings of Hanafy (1985) and Tabana (1994), who indicated that, total VFA's concentrations positively correlated with $\mathrm{pH}$ value of silage.

Table (1): Silage quality at zero time and opening day.

\begin{tabular}{lcccc}
\hline \multirow{2}{*}{ Item } & \multicolumn{2}{c}{ Zero time } & \multicolumn{2}{c}{ At open day } \\
\cline { 2 - 5 } & Corn silage & Quinoa silage & Corn silage & Quinoa silage \\
\hline DM\% & 29.68 & 26.89 & 32.37 & 30.56 \\
TVFA's(meq/g) & 2.66 & 1.07 & 5.22 & 3.95 \\
pH & 6.32 & 6.65 & 4.02 & 4.36 \\
NH3-N,\%of DM & 0.14 & 0.44 & 0.75 & 1.27 \\
Lactic acid,\% of DM & 1.05 & 0.85 & 5.58 & 3.02 \\
Acetic acid,\% of DM & 0.77 & 0.98 & 3.88 & 3.06 \\
Butyric acid,\% of DM & 0.15 & 0.11 & 1.07 & 0.96 \\
\hline
\end{tabular}

Ammonia-N concentration was more in quinoa silage than in corn silage (1.27 vs. $0.75 \%$ of DM); this could be related to the higher CP content of quinoa than corn. It also could be due to a the rapid decrease in $\mathrm{pH}$ value (Papastylianou et al. 2014 and Tabana,1994) and/or to the high DM content of quinoa silage, (table 3) which negatively correlated with NH3-N concentration of silage (Alomar, 1979 and Muck, 1987). In the meantime, $\mathrm{NH}_{3}-\mathrm{N}$ concentration in both silages was higher at the opening day than that at zero time; this could be attributed to the protiolytic analysis of $\mathrm{CP}$ to produce $\mathrm{NH}_{3}-\mathrm{N}(0.44$ and 0.14 vs. 1.27 and $0.75 \%$ of DM for quinoa and corn silage, respectively). During fermentation, protein is degraded into ammonia, amino acids, dipeptides, volatile basis and organic acids; strong ammonia odour indicates considerable loss in silage feeding value. Therefore, the high quality silage is characterized by low $\mathrm{NH}_{3}-\mathrm{N}$ concentration. Individual acid fractions showed an increase in lactic, acetic and butyric acids for both silages at the opening day than at zero time. These results were normally happened and could be related to the microbial protolytic activity which degrade protein content of the ensiled feedstuff to lactic acid which is the main affected acid in maturing silage, and as much lactic acid was content as the silage could be good and the materials were preserved well (Rosaria, et al 2018).

\section{Fiber fractions:}

Cell wall constituents of experimental rations were presented in Table (2). All fiber fractions content of quinoa hay as NDF, ADF, ADL, hemicellulose and cellulose were found to be of higher values with significant difference $(\mathrm{P}<0.05)$ in compare with those of berseem hay, corn and quinoa silages. On the other hand, both silages of corn and quinoa showed an intermediate value of such fiber fractions. The 
lower $(\mathrm{P}<0.05)$ values of berseem could be related to lower feed intake of berseem in compare to corn silage from one side and its lower CF digestibility, (Table 4) from the other side.

Table (2): Cell wall constituents of experimental rations (mean $\pm \mathrm{SE}$ ).

\begin{tabular}{lrrrr}
\hline Item & \multicolumn{2}{c}{ Hay } & \multicolumn{2}{c}{ Silage } \\
\cline { 2 - 5 } & Berseem & Quinoa & Corn & Quinoa \\
\hline Fiber fraction (\%). & & & & \\
NDF & $54.84 \pm 0.16^{\mathrm{c}}$ & $58.77 \pm 0.25^{\mathrm{a}}$ & $56.55 \pm 0.42^{\mathrm{b}}$ & $56.88 \pm 0.21^{\mathrm{b}}$ \\
ADF & $49.88 \pm 0.23^{\mathrm{c}}$ & $52.95 \pm 0.37^{\mathrm{a}}$ & $50.99 \pm 0.15^{\mathrm{b}}$ & $50.74 \pm 0.26^{\mathrm{b}}$ \\
ADL & $44.95 \pm 0.15^{\mathrm{c}}$ & $49.05 \pm 0.17^{\mathrm{a}}$ & $46.76 \pm 0.22^{\mathrm{b}}$ & $46.94 \pm 0.11^{\mathrm{b}}$ \\
Hemocellulose & $55.65 \pm 0.22^{\mathrm{c}}$ & $60.43 \pm 0.33^{\mathrm{a}}$ & $59.98 \pm 0.31^{\mathrm{b}}$ & $58.09 \pm 0.22^{\mathrm{b}}$ \\
Cellulose & $58.66 \pm 0.28^{\mathrm{c}}$ & $62.62 \pm 0.18^{\mathrm{a}}$ & $60.77 \pm 0.12^{\mathrm{b}}$ & $59.89 \pm 0.15^{\mathrm{b}}$ \\
\hline
\end{tabular}

$a, b, c$ Means within rows with different superscripts are significantly different $(P<0.05)$.

\section{Chemical composition:}

Chemical composition and fiber fractions of barley grains and experimental ingredients (on DM basis \%) are presented in Table (3). Crude protein (CP) content of quinoa hay indicated higher CP content compared with berseem hay $(15.38 \%$ vs. $12.47 \%)$, the same trend was also observed for quinoa silage form, where quinoa silage showed $14.59 \% \mathrm{CP}$ compared to $8.39 \%$ for corn silage.

Crude fiber of quinoa hay was found to be faraway, lower than that of berseem hay (11.60 vs. $22.73 \%$ ). Similar observation was noticed in quinoa silage in compare with corn silage (10.05 vs. $24.88 \%)$. Ether extract content was little pit more in quinoa hay than berseem hay (1.73 vs. $1.62 \%)$, but it was lower in quinoa silage than that in corn silage (1.78 vs. 1.97\%). Carbohydrate content expressed as NFE showed that quinoa either in the form of hay or silage showed higher values than berseem hay and corn silage (62.22 and 64.16 vs. 54.63 and 56.02\%, respectively). Ash content of quinoa indicated quiet similar in the form of hay or silage, in compare with berseem hay or corn silage (9.07, 9.42 vs. 8.55 and $8.74 \%$, respectively). Fiber fractions content of quinoa hay or silage were found to be lower than that in berseem or corn NDF, ADF and $\mathrm{ADL}(57.48,54.85 ; 30.88,29.78 ; 7.24$ and 7.05\%, respectively) Zbigniew, et al, 2018 and El-Sayed, et al 2015). Quinoa hay or silage had quiet similar content of hemicellulose to that of corn silage, but it was more than that of berseem. Berseem and corn silage showed more cellulose content than that of quinoa hay or silage.

Table (3): Chemical composition and fiber fractions of barley grains and experimental forage rations (on DM basis \%).

\begin{tabular}{|c|c|c|c|c|c|}
\hline \multirow[t]{2}{*}{ Item } & \multirow[t]{2}{*}{$\mathrm{BG}^{*}$} & \multicolumn{2}{|c|}{ Hay } & \multicolumn{2}{|c|}{ Silage } \\
\hline & & Berseem & Quinoa & Corn & Quinoa \\
\hline DM & 88.24 & 88.69 & 88.42 & 32.37 & 30.56 \\
\hline $\mathrm{OM}$ & 96.58 & 91.45 & 90.93 & 91.26 & 90.58 \\
\hline $\mathrm{CP}$ & 11.42 & 12.47 & 15.38 & 8.39 & 14.59 \\
\hline $\mathrm{CF}$ & 8.56 & 22.73 & 11.60 & 24.88 & 10.05 \\
\hline $\mathrm{EE}$ & 2.89 & 1.62 & 1.73 & 1.97 & 1.78 \\
\hline NFE & 73.71 & 54.63 & 62.22 & 56.02 & 64.16 \\
\hline Ash & 3.42 & 8.55 & 9.07 & 8.74 & 9.42 \\
\hline NDF & 38.86 & 60.22 & 57.48 & 61.98 & 54.85 \\
\hline $\mathrm{ADF}$ & 22.66 & 36.43 & 30.88 & 35.27 & 29.78 \\
\hline ADL & 5.64 & 7.79 & 7.24 & 7.95 & 7.05 \\
\hline Hemicellulose & 11.20 & 23.79 & 26.60 & 26.71 & 25.07 \\
\hline Cellulose & 17.02 & 28.64 & 23.64 & 27.32 & 22.73 \\
\hline
\end{tabular}

$* B G=$ Barley grain

\section{Digestion coefficients and nutritive values:}

Data presented in Table (4), showed digestion coefficients, feeding values and nitrogen utilization of experimental rations. Animals fed berseem hay and corn silage containing diets exhibited higher $(\mathrm{P}<0.05)$ 
digestion coefficients of DM and OM values. Data of digestibility study confirmed the previous results of feeding corn silage compared to berseem hay or any other crop silages. No significant difference was found for digestibility coefficients of DM and OM between rations contained either quinoa hay or silage. The higher $(\mathrm{P}<0.05)$ digestion coefficient of $\mathrm{CP}$ was noticed for animals fed corn silage while lower $\mathrm{CP}$ digestion coefficient value was found for quinoa hay containing rations $(59.48 \%)$. The higher $(\mathrm{P}<0.05)$ $\mathrm{CF}$ digestion coefficient was observed for animals fed quinoa silage (61.35\%), followed by those fed quinoa hay $(59.51 \%)$. These could be due to its lower CF content $(11.60 \%$ in the hay and $10.05 \%$ in silage, table 1), respectively. Digestion coefficient of EE was quiet similar for animals fed rations contained berseem hay, corn and quinoa silages. Those fed quinoa hay containing rations recoded the lower $(\mathrm{P}<0.05)$ EE digestion coefficient. These could be due to the high content of EE in corn and quinoa silage from one side and the higher degradation of berseem hay in the rumen from the other side. Higher $(\mathrm{P}<0.05)$ NFE digestion coefficient $(68.66 \%)$ was found in animals fed berseem hay containing rations, followed by the corresponding animals fed rations contained either quinoa hay $(65.13 \%)$ or corn silage $(66.71 \%)$. The lower $(\mathrm{P}<0.05)$ NFE digestion coefficient value $(64.52 \%)$ was recorded for animals fed quinoa silage. The higher digestion coefficient of NFE for berseem hay ration could be due to the higher solibility of berseem in the rumen compared to other different rations. And, although quinoa silage indicated higher content of NFE (64.16\%, Table 3); it showed lower NFE digestion coefficient; this might be referred to its content of some anti-nutritional factors (tannins and saponins. etc...). These results are in agreement with the findings of (Hanafy et al.; 2013)

Higher $(\mathrm{P}<0.05)$ feeding values were expressed either as (TDN or DCP \%) were shown by rations contained berseem hay or corn silage $(62.52,8.48 ; 61.98$ and $8.78 \%$, respectively) in compare with quinoa hay or silage. These could be related to their higher digestibility values $(\mathrm{P}<0.05)$ for most nutrients.

Table (4): Digestion coefficients, feeding value and nitrogen utilization of experimental rations (mean $\pm \mathrm{SE})$.

\begin{tabular}{|c|c|c|c|c|}
\hline \multirow[t]{2}{*}{ Item } & \multicolumn{2}{|c|}{ Hay } & \multicolumn{2}{|c|}{ Silage } \\
\hline & Berseem & Quinoa & Corn & Quinoa \\
\hline $\mathrm{DMI} / \mathrm{g} / \mathrm{h} / \mathrm{d}$ & $591.99 \pm 12.52^{\mathrm{a}}$ & $438.60 \pm 21.23^{\mathrm{c}}$ & $631.29 \pm 14.23^{\mathrm{a}}$ & $495.15 \pm 21.85^{b}$ \\
\hline \multicolumn{5}{|c|}{ Digestion coefficients $(\%)$} \\
\hline DM & $64.24 \pm 0.56^{\mathrm{a}}$ & $62.08 \pm 0.48^{\mathrm{b}}$ & $64.05 \pm 0.39^{\mathrm{a}}$ & $62.07 \pm 0.42^{\mathrm{b}}$ \\
\hline $\mathrm{OM}$ & $65.70 \pm 0.33^{\mathrm{a}}$ & $63.22 \pm 0.41^{\mathrm{b}}$ & $64.95 \pm 0.37^{\mathrm{a}}$ & $63.40 \pm 0.27^{\mathrm{b}}$ \\
\hline $\mathrm{CP}$ & $61.27 \pm 0.28^{\mathrm{b}}$ & $59.48 \pm 0.37^{\mathrm{c}}$ & $63.01 \pm 0.42^{\mathrm{a}}$ & $60.89 \pm 0.25^{\mathrm{b}}$ \\
\hline $\mathrm{CF}$ & $56.36 \pm 0.53^{d}$ & $59.51 \pm 0.49^{b}$ & $58.56 \pm 0.47^{\mathrm{c}}$ & $61.35 \pm 0.32^{\mathrm{a}}$ \\
\hline $\mathrm{EE}$ & $65.37 \pm 0.47^{\mathrm{a}}$ & $62.94 \pm 0.55^{\mathrm{b}}$ & $65.82 \pm 0.35^{\mathrm{a}}$ & $66.68 \pm 0.37^{\mathrm{a}}$ \\
\hline NFE & $68.66 \pm 0.62^{a}$ & $65.13 \pm 0.58^{\mathrm{b}}$ & $66.71 \pm 0.28^{\mathrm{b}}$ & $64.52 \pm 0.44^{\mathrm{c}}$ \\
\hline \multicolumn{5}{|c|}{ Nutritive values $(\%)$} \\
\hline TDN & $62.52 \pm 0.27^{\mathrm{a}}$ & $60.23 \pm 0.32^{\mathrm{b}}$ & $61.98 \pm 0.29^{\mathrm{a}}$ & $60.49 \pm 0.33^{\mathrm{b}}$ \\
\hline DCP & $8.48 \pm 0.22^{\mathrm{a}}$ & $8.35 \pm 0.19^{\mathrm{b}}$ & $8.78 \pm 0.15^{\mathrm{a}}$ & $8.24 \pm 0.26^{\mathrm{b}}$ \\
\hline \multicolumn{5}{|c|}{ Nitrogen utilization $(\mathrm{g} / \mathrm{h} / \mathrm{d})$} \\
\hline N-Intake & $17.04 \pm 0.17^{\mathrm{a}}$ & $14.27 \pm 0.11^{\mathrm{c}}$ & $12.51 \pm 0.10^{\mathrm{d}}$ & $16.22 \pm 0.14^{\mathrm{b}}$ \\
\hline N-Retention & $3.46 \pm 0.12^{\mathrm{a}}$ & $1.92 \pm 0.06^{\mathrm{c}}$ & $2.63 \pm 0.09^{\mathrm{b}}$ & $2.16 \pm 0.11^{b}$ \\
\hline $\mathrm{NR} \% / \mathrm{NI}$ & $20.34 \pm 0.24^{\mathrm{a}}$ & $13.46 \pm 0.17^{\mathrm{c}}$ & $21.03 \pm 0.17^{\mathrm{a}}$ & $13.32 \pm 0.18^{\mathrm{b}}$ \\
\hline
\end{tabular}

Higher $(\mathrm{P}<0.05)$ nitrogen intake and $\mathrm{N}$-retention were noticed for rams fed berseem hay, while lower $(\mathrm{P}<0.05) \mathrm{N}$ balance was recorded for rams fed quinoa hay; this could be related to the more $\mathrm{N}$ excreted in both urine and feces, and could be attributed to the more anti-nutritional components in quinoa than the other roughages tested herein in the present study. Nitrogen utilization $(\mathrm{NR} / \mathrm{NI})$ was higher $(\mathrm{P}<0.05)$ for rams fed berseem hay or corn silage, this might be due to the more $\mathrm{N}$ intake and solubility of berseem and the more palatability and lower $\mathrm{N}$ excreted of corn silage, on the other hand.

\section{Milk production \& Milk chemical composition:}

Data presented in Table (5) showed that ewes fed corn silage ration indicated higher $(\mathrm{P}<0.05)$ values of daily milk yield and 4\% FCM values, while ewes fed quinoa silage showed lower $(\mathrm{P}<0.05)$ values. moreover, ewes fed rations contained corn silage showed $19 \%$ more milk yield than those fed quinoa silage containing ration. This result agreed with Oba and Allen (1999) Mahmoud et al., (1992) and 


\section{Salama et al.}

Bendary and Younis (1997). The same trend was also noticed for ewes fed berseem hay compared with the correspondings fed quinoa hay (441.63 vs. $365.44 \mathrm{~g} / \mathrm{h} / \mathrm{d})$. The same finding was also noticed for animals fed quinoa hay, which resulted consequently in lower milk yield by about $20 \%$ compared with ewes fed berseem hay containing rations. Results concerning superiority of ewes fed corn silage and those fed berseem hay yields could be related to the higher DM intake as succulent rations, besides their high quality as a juicy palatable rations and their higher DM, OM , CP digestion coefficients (\%), TDN and DCP intake (table 4), compared to quinoa rations which seemed to be of lower palatability. Concerning $4 \%$ fat corrected milk $(\mathrm{FCM})$, results obtained pointed out to $(\mathrm{P}<0.05)$ differences among treatments. Ewes fed corn silage ration showed the higher $(\mathrm{P}<0.05)$ values, while those fed quinoa silage showed the lowest $(\mathrm{P}<0.05)$ values through all weeks of fat corrected milk as well. Ewes fed quinoa silage produced lower (FCM) by about $30 \%$ than ewes fed corn silage rations. The same trend was also noticed for ewes fed ration contained berseem hay compared to the corresponding fed quinoa silage, whereas quinoa indicated lower FCM than berseem hay ration by about $27 \%$. Similar results were noticed for ewes fed berseem hay, in compare with ewes fed quinoa hay. These results might be attributed to the higher crude fiber content for corn silage and berseem hay which led to improve $(\mathrm{P}<0.05)$ milk yield and milk fat yield and percentage compared with the quinoa silage and hay.

Daily fat percentage during the entire lactation period in the four groups were 4.3, 3.8, 4.2 and $3.5 \%$, respectively. The quinoa groups either in the form of hay or silage showed lower $(\mathrm{P}<0.05)$ values, while berseem hay and corn silage showed higher $(\mathrm{P}<0.05)$ values. It was noticed that quinoa silage indicated lower fat $(\%)$, but without significant differences $(\mathrm{P}>0.05)$ with quinoa hay group. On the other hand, berseem hay or corn silage rations had quiet similar fat $(\%)$. These results could be related to the lower $\mathrm{CF}$ content of quinoa than that of both berseem and corn (11.60 and 10.05 vs. 22.73 and 24.88\%, respectively, table 3). Concerning daily fat yield $(\mathrm{g} / \mathrm{h})$, the same result was observed for milk fat yield, where quinoa rations indicated lower $(\mathrm{P}<0.05)$ milk fat yield compared with berseem hay or corn silage rations. Corn silage recorded the higher milk fat yield than that of berseem hay, but without significant difference $(\mathrm{P}>0.05)$. The obtained results could be referred to the higher $(\mathrm{P}<0.05)$ milk yield for ewes fed corn silage $(464.19 \mathrm{~g} / \mathrm{h} / \mathrm{d})$ than those fed berseem hay $(441.63 \mathrm{~g})$.

As for protein percentage, the quinoa groups showed higher $(\mathrm{P}<0.05)$ values, while berseem hay or corn silage showed lower $(\mathrm{P}<0.05)$ values. On the other hand, berseem hay or corn silage rations had quiet similar protein $(\%)$ values, without significant differences between them. The obtained results could be explained by the lower $(\mathrm{P}<0.05)$ milk yield of ewes fed quinoa silage $(391.50 \mathrm{~g})$, and quinoa hay $(365.44$ $\mathrm{g})$, respectively.

Milk protein yield $(\mathbf{g})$, showed that ewes fed quinoa hay exhibited lower $(\mathrm{P}<0.05)$ value compared to the other different rations.

As for total solids, no significant $(\mathrm{P}>0.05)$ differences were observed among different rations; ranged between $(12.11$ to $12.55 \%)$.

Table (5): Milk yield; 4\% FCM, fat \% and fat yield (g), protein \% and protein yield (g) and TS\% of the experimental rations.

\begin{tabular}{lcccc}
\hline Item & \multicolumn{2}{c}{ Hay } & Corn & Quinoa \\
\cline { 2 - 5 } & Berseem & Quinoa & $464.19 \pm 63.05^{\mathrm{a}}$ & $391.50 \pm 53.04^{\mathrm{c}}$ \\
\hline Milk yield (g/h/d) & $441.63 \pm 67.26^{\mathrm{b}}$ & $365.44 \pm 60.27^{\mathrm{d}}$ & $472.36 \pm 59.75^{\mathrm{a}}$ & $361.65 \pm 44.88^{\mathrm{b}}$ \\
$4 \%$ FCM & $459.25 \pm 65.74^{\mathrm{a}}$ & $365.44 \pm 60.27^{\mathrm{b}}$ & $4.2 \pm 0.09^{\mathrm{a}}$ & $3.5 \pm 0.11^{\mathrm{b}}$ \\
Fat \% & $4.3 \pm 0.09^{\mathrm{a}}$ & $3.8 \pm 0.10^{\mathrm{b}}$ & $19.11 \pm 0.31^{\mathrm{a}}$ & $13.67 \pm 0.37^{\mathrm{b}}$ \\
Fat yield (g) & $18.84 \pm 0.22^{\mathrm{a}}$ & $13.42 \pm 0.34^{\mathrm{b}}$ & $3.50 \pm 0.12^{\mathrm{b}}$ & $3.97 \pm 0.09^{\mathrm{a}}$ \\
Protein \% & $3.63 \pm 0.12^{\mathrm{b}}$ & $4.12 \pm 0.06^{\mathrm{a}}$ & $16.03 \pm 0.17^{\mathrm{a}}$ & $15.46 \pm 0.28^{\mathrm{a}}$ \\
Protein yield (g) & $15.82 \pm 0.33^{\mathrm{a}}$ & $14.98 \pm 0.26^{\mathrm{b}}$ & $12.34 \pm 0.14$ & $12.11 \pm 0.12$ \\
Total solid\% (TS) & $12.55 \pm 0.18$ & $12.28 \pm 0.10$ &
\end{tabular}




\section{CONCLUSION}

It could be concluded that quinoa silage or hay, are valid substitutions for some other medium quality roughages in sheep rations. Potentiality, it can be beneficial for smallholder's to cultivate quinoa during the period of forage scarcity, especially in drought affected areas, as well as in an infertile land.

\section{REFERENCES}

AOAC (2012). Association of Official Analytical Chemists. Official Methods of Analysis of AOAC International, 19th ed. AOAC, Gaithersburg, MD, USA

Alomar, C. D. (1979). Chemical evaluation of ensiled rumen contents. Agro. Sur., 7:89. (Nut. Abs\& Rev., 1980, 50: 5206 ).

Bendary, M. M. and M. A., Younis (1997). Evaluation of maize stalks for feeding dairy cows. Egypt. J. Appl. Sci., 12(8) 11-25.

Darwinkel, A. and O. Stolen (1998) Understanding the quinoa crop: Guidelines for growing in temparate regions of N.W. Europe. Brochure of the The Quinoa Project. AIR 2 Programme - contract \#931426. pp 20. (Cited from Quinoa an alternative foarge crop in organic dairy farming, VanSchotten and Pinxterhuis, 2003).

Duncan, D.B. (1955). Multiple Range and Multiple F Test. Biometrics, 11:10.

El-Shazly, K. (1958). Some studies of the nutritive value of some commen Egyptian feeding stuffs. 1. Nitrogen retention and ruminal ammonia curves. J. Agri. Sci., 51:1.

El-Sayed, F. A. and W.M.A. Sadik (2015). Effect of feeding different types of silage (Berseem or Kochia and their mixture with fodder beet) on growth performance of growing male goats. J. Animal and Poultry Prod., Mansoura Univ., 6 (8): 567- 581.

Everson, R.A., N.A. Jorgensen and G.P. Barrington (1971). Effect of bentonite, nitrogen source and stage of maturity on nitrogen redistribution in corn silage. J. Dairy Sci., 54: 1482 - 1490.

Ling, E.R.(1963). A text book of dairy Chimistry. $3^{\text {rd }}$ ed., vol. 11.Chapman and Hall Ltd., London.

Hanafy, M. A. (1985). Nutritional evaluation of ensiled by products with or without forage. Ph. D. Thesis, Fac. of Agric., Cairo Univ. Egypt.

Hanafy M. A., Fahmy A. A., Farghaly M. S. and Afaf A. El-Shereef (2013). Effect of different treatments on digestibility coefficients and nutritive values of Kochia plant by sheep. Egypt J. Nutr. and Feeds, 16 (2) Iss. 257 - 265.

Mahmoud, A.M.; Bendary, M.M.;Harfoush,M.A. and Ramadan, G.A.(1992). Effect of feeding lactating cows corn silage on milk production compared with traditional summer and winter rations. J.Agric. Sci. Mansoura Univ., 17 (9): 2904- 2915.

Muck, R. E.(1987). Dry matter level effects on alfalfa silage quality . 1. Nitrogen transformations. Trans. Am. Soc. Agric. Eng. 30:7. (C.F. Muck1988).

Oba, M., and M.S. Allen (1999). Effects of brown midrib 3 corn mutation in corn silage on dry matter intake and productivity of high yielding dairy cows. J. Dairy Sci., 82:135-142.

Oscar, B.T.; German, D.M.M.; Jose, L.R.O. and Abel-Munoz,O.(1995). Forage evaluation of 18 varieties of quinoa (chenopodium quinoa Willd.) in Montecillo, Mexico. Rev. Fac. Agron. (LUZ) 12:1-79 (Abst.).http://www.revfacagronluz.org.ve/v12 1/v21z060.html.

Papastylianou, P; I. Kakabouki; E. Tsiplakou; I. Travlos; D. Bilalis; D. Hela; D. Chachalis; G. Anogiatis. and G. Zervas (2014). Effect of fertilization on yield and quality of biomass of quinoa (Chenopodium quinoa Willd.) and green amaranth (Amaranthus retroflexus L.). Bulletin UASVM Horticulture, 71 (2): 288-292.

Repo-Carrasco, R; C. Espinoza and S.E. Jacobsen (2003). Nutritional value and use of the Andean crops quinoa (Chenopodium quinoa) and kañiwa (Chenopodium pallidicaule). Food Reviews International, 19 (1e2): 179-189. 


\section{Salama et al.}

Rosaria, M; Mariangela C; Giovanni A; Francesco, C; Maria G. M, Antonella, S; Agostino, S. and Marzia A., (2018).Effect of Diet Supplementation with Quinoa Seed and/or Linseed on Immune Response, Productivity and Meat Quality in Merinos Derived Lambs. Animals (Basel) Vol. 8(11): 2018.

Ruiz, T.M., E. Bernal, C.R. Staples, L.E. Sollenbereger and R.N. Gallaher (1995). Effect of dietary neutral detergent fiber concentration and forage source on performance of lactating cows. J. Dairy Sci., 78: 305 .

SAS, (2002). Statistical Analysis System. SAS User's Guide Statistics. SAS Inst. Inc. Ed., Cary, NC.

Tabana, A. S. (1994). Utilization of corn and sunflower plant residues in ruminants nutrition. M. Sc. Thesis, Fac. Of Agric., Cairo Univ., Egypt.

Van Schooten, H.A.and Pinxterhis, J.B. (2003). Quinoa as an alternative forage crop in organic dairy farming. Optimal Forage Systems for Animal Production and Environment Grassland Scince in Europe, Vol.8.

Van Soest, P.J.; J.B. Robertson and B.A. Lewis (2010). Methods for Dietary Fiber, Neutral Detergent Fiber, and Nonstarch Polysaccharides in Relation to Animal Nutrition. Journal of Dairy Science. https://doi.org/10.3168/jds.s0022-0302(91)78551-2

Warner, A. C. I. (1964). Production of volatile fatty acids in the rumen, methods of measurement. Nutr. Abst. And Rev., 34: 339.

Weiss,W. P. (1993). Predicting energy values of feeds. J. Dairy Sci., 76:1802.

Zbigniew, P; G. Krzysztof and P. Lucyna (2018). The influence of additives facilitating ensiling on the quality of quinoa (Chenopodium quinoa Willd.) silage. J. of Central European Agriculture, 19(3): 607614.
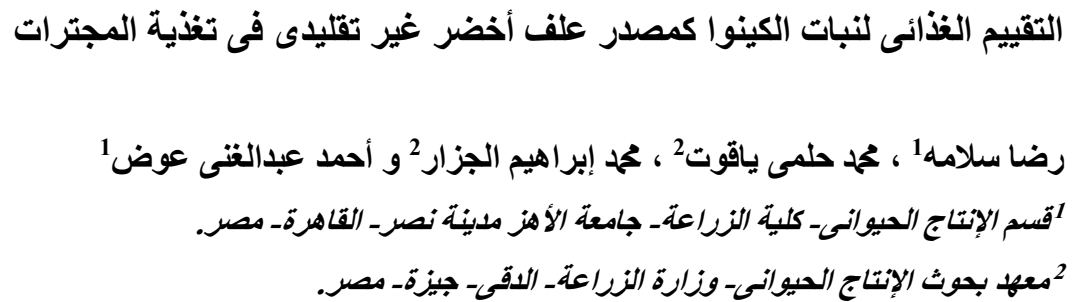

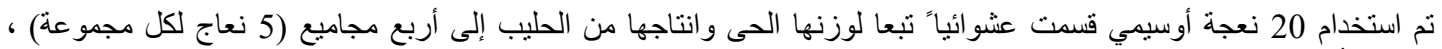

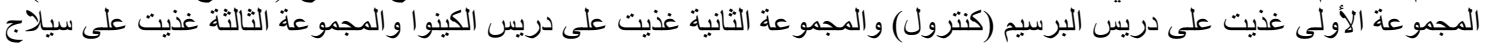

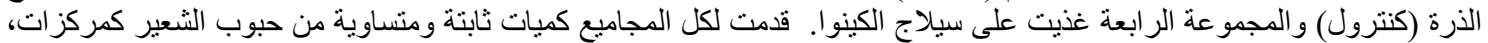

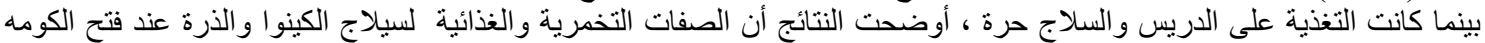

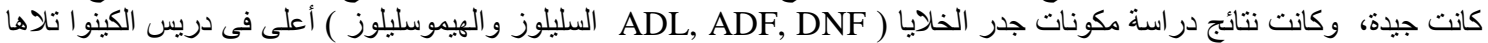

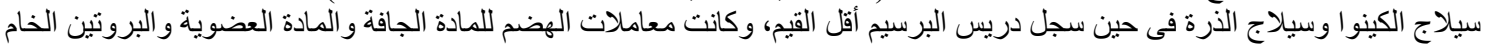

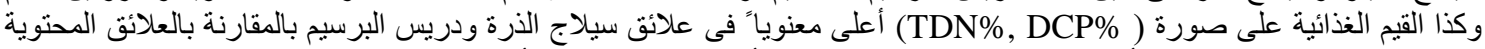

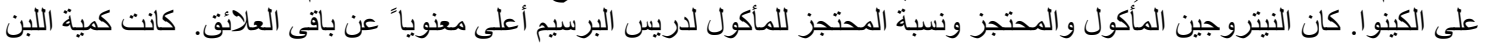

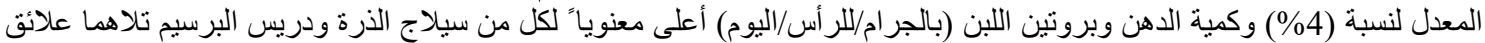
الكينو ا.

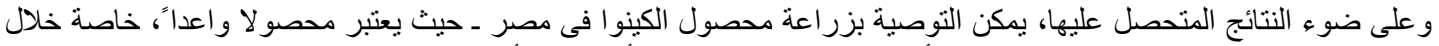

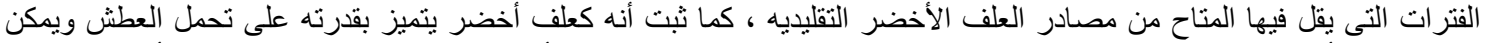

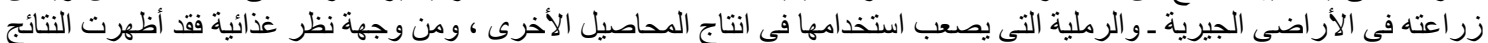

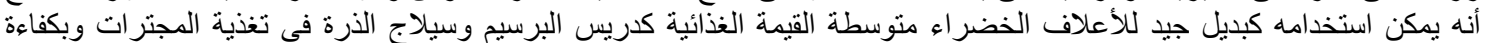

